\title{
Reaction of rat mothers to experimental disturbance
}

\author{
M. H. S. LEE and D. I. WILLIAMS \\ The University, Hull, HU6 7RX, England
}

\begin{abstract}
Litters were either handled (LH), or mother-only handled $(\mathrm{MH})$, or left undisturbed (NH) on six daily sessions after birth. They were observed on the 7 th day, after all pups had been handled, and cross fostered to give litters split so that half the pups had experienced a different, and half the same, experience as the natural young of the foster-mother. Mothers did not distinguish between young having different histories. NH mothers reared more, and spent more time retrieving pups, than the other groups. Handling thus has a direct effect on the mother. It increases maternal activity but not necessarily maternal care.
\end{abstract}

Handling rodents prior to weaning has been shown to produce long-lasting physiological and behavioral changes (cf. Denenberg, 1969). One potent theory sees modification of maternal behavior as mediating this effect (Meier \& Schultzman, 1968). Implicit in these studies is the notion that stimulation acts directly on the neonate to change its stimulus qualities in some way (e.g., ultrasound: Bell, Nitschke, Gorry, \& Zachman, 1971) so as to elicit a response from the mother. Thus they compare the behavior of disturbed and undisturbed litters immediately following treatment. But in doing so, they confound the results of stimulating the young with the inevitable disturbance of the mother; it would be wrong, therefore, to attribute all maternal behavior changes specifically to the effects of stimulating the young. The present study sought to investigate this problem by handling all litters just prior to observation, and comparing litters that had, or had not, previously experienced handling, and also examining the mothers' behavior to pups which had had different treatment.

\section{METHOD}

\section{Subjects}

Fifteen black-hooded rats (strain PVG/C) with litters born on the same day were used. Each litter was housed in an opaque plastic cage measuring 42 by 22 by $17 \mathrm{~cm}$ high with shredded paper bedding. The lids of stainless steel held food and water, which were freely available except for observation periods. The laboratory was maintained on a 16-h daylight schedule with the onset of the dark period at $2200 \mathrm{~h}$.

\section{Procedure}

At birth, litters were culled to six and allocated to one of three groups, which received the following treatment on six consecutive daily sessions: (1) (LH) Pups and mother were handled. The procedure was as used by Williams and Russell (1972) and involved removing the mother to a holding cage after which pups were removed individually to separate cells in a wooden box; each animal was then returned to the home cage in a like manner. The whole treatment took approximately $3 \mathrm{~min}$. (2) $(\mathrm{MH})$ The mother was removed as for the LH group, but the pups remained untouched. (3) (NH) The litter and mother were undisturbed. On Day 7, pups were marked with a nontoxic dye and cross fostered such that each mother received three pups from the group in which she belonged, and three which had experienced a different treatment. The allocation for NH mothers was NH and LH pups; for MH mothers, the allocation was MH and NH pups; LH mothers received LH and MH pups. The mothers were not handled at this stage.

One hour after fostering, and at two later sessions, $2 \mathrm{~h}$ apart, the behavior of each mother was observed and a retrieval test carried out. The procedure involved removing the mother to a holding cage while moving the young away from the designated nest site, then replacing the mother and fitting a clear Perspex lid to the cage. The litter was then observed for $5 \mathrm{~min}$. Three "blind" observers were used; no observer tested the same litter twice. Records were made of latency to retrieve and total time taken to retrieve the whole litter. In addition, a five-track punch tape encoder situated in a separate room was used to record: (1) active nursing, (2) nursing and nest building, (3) nursing and licking pups, (4) nursing and miscellaneous behavior (not related to pup care), (5) inactive nursing, (6) licking pups, (7) nest building, $(8,9,10)$ retrieving respectively, $\mathrm{NH}, \mathrm{MH}$, or $\mathrm{LH}$ pups, (11) lying alone, (12) alone and miscellaneous behavior, and (13) rearing (both forepaws off the cage floor).

\section{RESULTS}

The frequency and duration of each behavioral category observed was obtained from the punch tape after computation. Data were then pooled over three trials, and each category was analyzed using nonparametric procedures. Only two measures, rearing and retrieving time, differentiated between the groups. NH mothers spent more time rearing (median $=155 \mathrm{sec})$ than both treated groups $(\mathrm{U}=$ ( $U=7, \mathrm{n}_{1}=5, \mathrm{n}_{2}=10, \mathrm{p}<.05$, two-tailed test), this being more marked with MH mothers (median $=74 \mathrm{sec}$ ) than $\mathrm{LH}$ (median $=110 \mathrm{sec}$ ). Similarly, NH mothers made more rears (median $=24$ ) than both $\mathrm{MH}$ (median $=18$ ) and $\mathrm{LH}$ mothers $($ median $=14)\left(U=8, n_{1}=5, n_{2}=10, p<.05\right.$, two-tailed test). NH mothers spent more time retrieving (median $=45 \mathrm{sec}$ ) than both $\mathrm{MH}$ (median $=12 \mathrm{sec}$ ) and LH mothers (median $=12 \mathrm{sec}$ ) ( $U=4, n_{1}=5, n_{2}=10, p<.02$, two-tailed test); no preference could be demonstrated in terms of time spent retrieving the different categories of pups. 


\section{DISCUSSION}

During the observation period, most of the lactating females' behavior was nonmaternal. Their time was spent burrowing beneath bedding paper, sniffing, self-grooming, and rearing. Nursing of the young was infrequent, and, where this did occur, was generally pup initiated. The mothers were very active, changing from one activity to another in a matter of seconds. Rate of change of activity did not differentiate between groups. If, however, we adopt Lat's (1967) use of rearing as an arousal index, then $\mathrm{NH}$ females exhibited a higher excitability level than the other two groups. Mothers thus react initially to disturbance but then adapt to it.

In an earlier attempt to control for disturbance factor concomitant with handling, Lee and Williams (1975) observed litters starting $25 \mathrm{~min}$ after treatment, so allowing a settling down period after handling. They showed long-lasting effects which, in contrast to transient effects previously reported (e.g., (Priestnall, 1973; Sherrod, Connor, \& Meier, 1974), were characterized by reduced rather than increased maternal involvement. The present results enable us to reconcile these findings. Disturbance may produce a transient increase in maternal activity, but this may be maladaptive and lead to a decrease in maternal care. The increase in retrieving shown here by. $\mathrm{NH}$ mothers, for example, represents aberrant behavior, for this was not because NH mothers retrieved more pups; the proportion was the same across groups. Rather, NH mothers would carry a pup about and sometimes replace it in its original position. Retrieving was thus recorded up to 15 times in a litter of only six pups!

Even though mothers may partially adapt to repeated handling of the young, they may still exhibit hyperactivity compared to controls; this could result in the disruption of the nest site and scattering of the young found by Lee and Williams (1975).

The failure to show a differential response by the mother to pups having different histories cannot be taken as a crucial test. The design was incomplete and the numbers small. It is nevertheless consistent with other reports (e.g., McIver \&
Jeffrey, 1967), and suggests that changes in pup stimulus qualities that result from handling may not be a dominant factor in precipitating changes in maternal behavior. The treatment may affect the mother directly.

\section{REFERENCES}

Bell, R. W., NitschKe, W., GorRy, T. H., \& ZaChMan, T. A. Infantile stimulation and ultrasonic signalling: A possible mediator of early handling phenomena. Developmental Psychobiology, 1971, 4, 181-191.

Denenberg, V. H. The effects of early experience. In E. S. E. Hafez (Ed.), The behaviour of domestic animals. London: Balliere. Tindall, and Cassell, 1969.

LÁT, J. Nutrition, learning and adaptive capacity. In M. R. Kare, \& O. Maller (Eds.), The chemical senses and nutrition. Baltimore: John Hopkins Press, 1967.

LeE, M. H. S., \& Williams, D. I. Long term changes in nest condition and pup grouping following handling of rat litters. Developmental Psychobiology, 1975, 8, 91-95.

MCIVER, A. H., \& JefFrey, W. E. Strain differences in maternal behavior in rats. Behaviour, 1967, 28, 210-216.

Meier, G. W., \& Schultzman, L. H. Mother-infant interactions and experimental manipulation: Confounding or misidentification? Developmental Psychobiology, 1968, 1, 141-145.

Priestrall, R. Effects of handling on maternal behavior in the mouse (Mus musculus): An observational study. Animal Behaviour, 1973, 21, 383-386.

Sherrod, K. B., Connor, W. H., \& Meier, G. W. Transient and enduring effects of handling on infant and maternal behavior in mice. Developmental Psychobiology, 1974, 7, 31-37.

Williams, D. I., \& Russell, P. A. Open field behavior in rats: Effects of handling, sex and repeated testing. British Journal of Psychology, 1972, 63, 593-596.

(Received for publication March 21, 1976.) 